\title{
Chemical and Microbiology Analysis of Salted Anchovies (Stolephorus sp.) in East Denpasar Traditional Market
}

\author{
DellaX'ma Nandari', Anak Agung Made Semariyani², Ni Made Ayu Suardani Singapurwa ${ }^{3}$ \\ Department of Food Science and Technology Faculty of Agricultural, Warmadewa University, \\ Denpasar-Bali, Indonesia \\ ${ }^{1}$ E-mail: della.nandari09@gmail.com \\ ${ }^{2}$ E-mail: semariyanimega@gmail.com \\ ${ }^{3}$ E-mail: a.suardani@ymail.com
}

\begin{abstract}
Jengki anchovies are one of the raw food ingredients that are preserved using salt. Salting is done to reduce the water content in the fish so that bacteria cannot live and develop. This study aims to determine the chemical and microbiological contamination of salted anchovies in East Denpasar Traditional Market. This research is a descriptive study using survey and experimental methods in the laboratory. Based on data from the Department of Industry and Trade in Denpasar, there are 7 traditional markets in East Denpasar. The number of samples studied was 43 samples from 75 existing populations. The parameters of this research were formaldehyde, moisture content, TPC, E. coli, and organoleptic. The results showed that none of the 43 samples contained formalin. The results of the water content test were obtained that all samples met the SNI 8273: 2016 requirements. From the results of the TPC test, 35 samples met the requirements and 8 samples exceeded the limits set by SNI 8273: 2016, namely the maximum limit of TPC contamination, namely $1.0 \times 105$ colonies/gram. The E. coli test results from 43 samples met the SNI 8273: 2016 requirements, namely the maximum limit of E. coli contamination $<3.6$ APM / gram. From the results of the organoleptic test on appearance, smell, taste, texture, fungus, and overall acceptance, all assessments were significantly different, with the characteristics of a dull to clean bright appearance, specific to the type, specific odor but less strong, salty taste and a less specific type, dry solid texture too dense less dry.
\end{abstract}

Keywords: Jengki anchovies, Formalin, Total Plate Count, E.coli

\section{Introduction}

Food safety can be determined by the presence or absence of contamination from indigestible materials such as plastics, metals, or materials that can interfere with human digestion. Chemical contaminants come from hazardous chemical substances that cannot be used as food ingredients such as formaldehyde and pesticides as well as restricted food additives such as ascorbic acid, lactic, citrate, nitrate, and other food additives. Microbiological hazards come from the presence of pathogenic bacteria and toxins that are generated in foodstuffs. Healthy food is one of the factors that play a role in health, healthy food is needed by the human body. One of the ways to improve the quality of human resources is determined by the quality of food consumed.

Jengki anchovies are one of the foods that use a natural preservative in the form of salt. Salting the spoilage process can be inhibited so that the fish can be stored longer as well as its ability to inhibit bacterial growth and the activity of enzymes that cause putrefaction in the fish's body. Fish that have died decompose very quickly compared to beef, fruit, or vegetables [1]. 


\section{Material and Methods}

\subsection{Place and time of research}

The research was conducted at the Laboratory of the Faculty of Agriculture, Warmadewa University, and Denpasar Veterinary Center. This research was conducted from March 2020 to June 2020.

\subsection{Research Material}

\subsubsection{Tool}

Plastic bags for storing samples, Durham tubes, Petri dishes, desiccators, test tubes, $1 \mathrm{ml}, 2 \mathrm{ml}, 5$ $\mathrm{ml}, 10 \mathrm{ml}$ pipettes, media bottles, scissors, tweezers, inoculation needles, stomacher, bunsen burners, pH meter, analytical scale, drying oven, clamp pliers, magnetic stirrer, tube shaker (vortex), incubator, water bath, autoclave, sterile cabinet (clean bench), refrigerator, freezer, volumetric pipette, colony counter), and needle inoculation.

\subsubsection{Ingredient}

Jengki anchovies from 7 Traditional Markets, $0.5 \%$ phenylhydrazine solution, 5\% sodium nitroprusside solution, $10 \%$ natrium hydroxide ocean, $37 \mathrm{Wt} . \%$ Purity formaldehyde standard (Cat PS-2031), distilled water, BPW (Buffered Pepton Water) 0.1\%, BGLBB (Brilliant GreenLactose Bile Broth), LSTB (Lauryl Sulfate Tryptose Broth), ECB (Escherichia Coli Broth), L-EMBA (Levine Eosin Methylene Blue Agar) MR-VP (Methyl Red-Voges Proskauer ), PCA (Plate Count Agar) KCB (Koser Citrate Broth), SCA (Simmons Citrate Agar), Kovac Reagent, Voges-Proskauer Reagent (VP), BPW 0.1\% (Buffered Pepton Water 0.1\%) potassium chromate $\left(\mathrm{K}_{2} \mathrm{CrO}_{4}\right) 5 \%$, and $\mathrm{AgNO}_{3} 0.1$ $\mathrm{N}$, physiological salts of $0.85 \% \mathrm{NaCl}$.

\subsection{Research Design}

This type of research is descriptive research. The survey was conducted based on the existing population. The population is the whole unit of analysis that has general observable characteristics that will be the research target. This research uses survey and experimental methods in the laboratory.

The method used in sampling was the survey method with a simple random sampling technique, namely the technique of obtaining samples directly carried out in the sampling unit. The sampling technique was carried out once for each of the salted jengki fish traders randomly at 7 traditional markets in East Denpasar District at 14:00 WITA with samples of salted anchovy jengki. A sample of 1 ounce of traders will be taken then put into a plastic container and the analysis will be carried out on the same day as the sampling. This aims to avoid changes in terms of physical, chemical, and microbiological conditions.

Based on the Slovin Formula, which is the determination of the minimum number of samples to be studied with a set margin of error of $10 \%$ ( $90 \%$ confidence level), the calculations are as follows:

$$
\boldsymbol{n}=\frac{\mathbf{N}}{\left(\mathbf{1}+\left(\boldsymbol{N} X e^{2}\right)\right)}
$$

Where $\mathrm{n}$ is the sample, $\mathrm{N}$ is the population and " $\mathrm{e}$ " is the margin of error $(10 \%)$. With the Slovin formula, the minimum number of samples to be studied is 43 samples from 75 existing populations. 


\subsection{Research Implementation}

The stages of this research consisted of surveys of anchovy salted fish traders to obtain researchrelated data, sampling randomly selected anchovy salted fish traders for sampling, analysis of samples in the laboratory which included: formalin analysis, moisture content, Escherichia coli bacteria, and Total Plate Count (TPC) as well as sensory.

\subsection{Data Analysis}

From the research data obtained, a descriptive analysis was carried out. The descriptive analysis carried out refers to SNI 8273-2016 concerning the quality and safety requirements of salted fish. From the results of this analysis, it is known that the safety level of the anchovies salted fish sold in East Denpasar Traditional Market in terms of chemical analysis and microbial contamination.

\section{Results and Discussion}

\subsection{Formalin}

The identification of formaldehyde was carried out qualitatively on samples of salted anchovies circulating in traditional markets in East Denpasar. The results showed that 43 samples of salted anchovies contain negative formalin.

According to [2], formalin is one of the prohibited additives for food. The use of formaldehyde in food is prohibited because it can have adverse effects on health. Previously researched the formaldehyde content of anchovies salted fish circulating in the Traditional Market of Denpasar City, the results showed that there were 7 samples or about $29.2 \%$ positive for formaldehyde out of 24 total samples of salted anchovies. identified from the Traditional Market of Denpasar City. In the results of this study, no samples of salted anchovies contain formaldehyde, this shows that there is already an awareness of the anchovies salted fish processors not to use formaldehyde as a preservative in food. The results of the formalin test can be seen in Table 1.

Table 1

Results of Testing the Formalin Levels in Salted Anchovy Jengki Circulating in East Denpasar Traditional Markets

\begin{tabular}{llccc}
\hline No & Market Name & Sample Code & Test Result & Information \\
\hline 1 & Yadnya Market & PT1 & negative & MS \\
2 & Yadnya Market & PT2 & negative & MS \\
3 & Yadnya Market & PT3 & negative & MS \\
4 & Yadnya Market & PT4 & negative & MS \\
5 & Gunung Sari Market & PT5 & negative & MS \\
6 & Gunung Sari Market & PT6 & negative & MS \\
7 & Gunung Sari Market & PT7 & negative & MS \\
8 & Gunung Sari Market & PT8 & negative & MS \\
9 & Gunung Sari Market & PT9 & negative & MS \\
10 & Gunung Sari Market & PT10 & negative & MS \\
11 & Gunung Sari Market & PT11 & negative & MS \\
12 & Kertha Sari Village Market & PT12 & negative & MS \\
13 & Kertha Sari Village Market & PT13 & negative & MS \\
14 & Kertha Sari Village Market & PT14 & negative & MS \\
15 & Tamba Market & PT15 & negative & MS \\
16 & Tamba Market & PT16 & negative & MS \\
17 & Tamba Market & PT17 & negative & MS \\
\hline
\end{tabular}


Chemical and Microbiology Analysis of Salted Anchovies (Stolephorus sp.) in East Denpasar Traditional Market

\begin{tabular}{|c|c|c|c|c|}
\hline 18 & Tamba Market & PT18 & negative & MS \\
\hline 19 & Tamba Market & PT19 & negative & MS \\
\hline 20 & Tamba Market & PT20 & negative & MS \\
\hline 21 & Tamba Market & PT21 & negative & MS \\
\hline 22 & Tamba Market & PT22 & negative & MS \\
\hline 23 & Tamba Market & PT23 & negative & MS \\
\hline 24 & Kerta Waringin Market & PT24 & negative & MS \\
\hline 25 & Kerta Waringin Market & PT25 & negative & MS \\
\hline 26 & Kerta Waringin Market & PT26 & negative & MS \\
\hline 27 & Kerta Waringin Market & PT27 & negative & MS \\
\hline 28 & Kerta Waringin Market & PT28 & negative & MS \\
\hline 29 & Kerta Waringin Market & PT29 & negative & MS \\
\hline 30 & Kerta Waringin Market & PT30 & negative & MS \\
\hline 31 & Kerta Waringin Market & PT31 & negative & MS \\
\hline 32 & Kerta Waringin Market & PT32 & negative & MS \\
\hline 33 & Kerta Waringin Market & PT33 & negative & MS \\
\hline 34 & Kerta Waringin Market & PT34 & negative & MS \\
\hline 35 & Kerta Waringin Market & PT35 & negative & MS \\
\hline 36 & Penatih Market & PT36 & negative & MS \\
\hline 37 & Penatih Market & PT37 & negative & MS \\
\hline 38 & Penatih Market & PT38 & negative & MS \\
\hline 39 & Penatih Market & PT39 & negative & MS \\
\hline 40 & Penatih Market & PT40 & negative & MS \\
\hline 41 & Tanjung Bungkak Market & PT41 & negative & MS \\
\hline 42 & Tanjung Bungkak Market & PT42 & negative & MS \\
\hline 43 & Tanjung Bungkak Market & PT43 & negative & MS \\
\hline
\end{tabular}

\subsection{Total Plate Count (TPC)}

Based on the research results, the total microbes of salted anchovies were $7.0 \times 101$ to $1.3 \times 107$ colonies/ g. Based on SNI 8273-2016, the maximum total microbial content is $1.0 \mathrm{x} 105$, this shows that there are samples of salted anchovies that do not meet the SNI can be seen in Table 2.

Table 2

TPC Test Results on Anchovies and Jengki Salted Fish Circulating in East Denpasar Traditional

\begin{tabular}{llccc}
\multicolumn{5}{c}{ Market } \\
\hline No & Market Name & Sample Code & Test Result & Information \\
\hline 1 & Yadnya Market & PT1 & $1.4 \times 10^{4}$ & MS \\
2 & Yadnya Market & PT2 & $1.4 \times 10^{3}$ & MS \\
3 & Yadnya Market & PT3 & $5.9 \times 10^{3}$ & MS \\
4 & Yadnya Market & PT4 & $5.4 \times 10^{3}$ & MS \\
5 & Gunung Sari Market & PT5 & $5.7 \times 10^{2}$ & MS \\
6 & Gunung Sari Market & PT6 & $2.3 \times 10^{3}$ & MS \\
7 & Gunung Sari Market & PT7 & $1.2 \times 10^{2}$ & MS \\
8 & Gunung Sari Market & PT8 & $1.6 \times 10^{3}$ & MS \\
9 & Gunung Sari Market & PT9 & $8.7 \times 10^{2}$ & MS \\
10 & Gunung Sari Market & PT10 & $2.9 \times 10^{3}$ & MS \\
11 & Gunung Sari Market & PT11 & $4.4 \times 10^{3}$ & MS \\
12 & Kertha Sari Village Market & PT12 & $6.6 \times 10^{3}$ & MS \\
13 & Kertha Sari Village Market & PT13 & $3.4 \times 10^{2}$ & MS \\
14 & Kertha Sari Village Market & PT14 & $2.4 \times 10^{5}$ & TMS \\
\hline
\end{tabular}




\begin{tabular}{|c|c|c|c|c|}
\hline 15 & Tamba Market & PT15 & $1.8 \times 10^{2}$ & MS \\
\hline 16 & Tamba Market & PT16 & $7.0 \times 10^{1}$ & MS \\
\hline 17 & Tamba Market & PT17 & $9.0 \times 10^{2}$ & MS \\
\hline 18 & Tamba Market & PT18 & $1.8 \times 10^{4}$ & MS \\
\hline 19 & Tamba Market & PT19 & $9.7 \times 10^{2}$ & MS \\
\hline 20 & Tamba Market & PT20 & $1.5 \times 10^{4}$ & MS \\
\hline 21 & Tamba Market & PT21 & $2.7 \times 10^{4}$ & MS \\
\hline 22 & Tamba Market & PT22 & $6.0 \times 10^{2}$ & MS \\
\hline 23 & Tamba Market & PT23 & $9.6 \times 10^{4}$ & MS \\
\hline 24 & Kerta Waringin Market & PT24 & $1.9 \times 10^{3}$ & MS \\
\hline 25 & Kerta Waringin Market & PT25 & $9.6 \times 10^{3}$ & MS \\
\hline 26 & Kerta Waringin Market & PT26 & $7.8 \times 10^{2}$ & MS \\
\hline 27 & Kerta Waringin Market & PT27 & $1.3 \times 10^{3}$ & MS \\
\hline 28 & Kerta Waringin Market & PT28 & $5.6 \times 10^{5}$ & TMS \\
\hline 29 & Kerta Waringin Market & PT29 & $5.6 \times 10^{3}$ & MS \\
\hline 30 & Kerta Waringin Market & PT30 & $3.6 \times 10^{3}$ & MS \\
\hline 31 & Kerta Waringin Market & PT31 & $2.6 \times 10^{6}$ & TMS \\
\hline 32 & Kerta Waringin Market & PT32 & $8.5 \times 10^{3}$ & MS \\
\hline 33 & Kerta Waringin Market & PT33 & $8.4 \times 10^{2}$ & MS \\
\hline 34 & Kerta Waringin Market & PT34 & $8.8 \times 10^{2}$ & MS \\
\hline 35 & Kerta Waringin Market & PT35 & $2.0 \times 10^{5}$ & TMS \\
\hline 36 & Penatih Market & PT36 & $2.2 \times 10^{5}$ & TMS \\
\hline 37 & Penatih Market & PT37 & $2.4 \times 10^{4}$ & MS \\
\hline 38 & Penatih Market & PT38 & $1.5 \times 10^{5}$ & TMS \\
\hline 39 & Penatih Market & PT39 & $3.4 \times 10^{5}$ & TMS \\
\hline 40 & Penatih Market & PT40 & $2.6 \times 10^{2}$ & MS \\
\hline 41 & Tanjung Bungkak Market & PT41 & $3.7 \times 10^{4}$ & MS \\
\hline 42 & Tanjung Bungkak Market & PT42 & $4.1 \times 10^{4}$ & MS \\
\hline 43 & Tanjung Bungkak Market & PT43 & $1.3 \times 10^{7}$ & TMS \\
\hline
\end{tabular}

Based on Table 2, the results of the Total Plate Count (TPC) test on 43 samples of salted fish, there are as many as 8 samples of salted anchovies that do not meet the Indonesian National Standard. According to [3], the water content in food ingredients affects the resistance of foodstuffs to microbial attack which is expressed as aw, namely the amount of free water that can be used by microorganisms for their growth. High water content is thought to result in high total bacteria in these foodstuffs. The microorganisms that are thought to be able to grow on anchovies are halophilic bacteria because mold, yeast, and bacteria require high aw values for their growth.

\subsection{Escherichia coli}

The presence of E. coli bacteria is an indicator of food safety. E. coli bacteria are a group of bacteria in the form of rods, gram-negative. These bacteria are used as an indicator of the presence of pollution from animal and human waste and indicate poor sanitation of water and food or processed products. Based on Table 3 the results of testing for E. coli bacteria in salted anchovies, all samples do not contain E.coli. This is by SNI 8273-2016 E. coli contamination, namely <3.6 APM / g. The absence of E. Coli in the anchovies salted fish samples sold by traders in traditional markets is thought to be due to the processing of salted anchovy fish and hygienic places of sale, and the equipment used is free from bacteria so that bacterial growth can be prevented. The presence or absence of Escherichia coli bacteria in anchovies can be caused by several factors, including conditions that do not support the growth of Escherichia coli bacteria [4]. 


\section{Table 3}

Testing results of e. Coli on salted anchovy jengki circulating in East Denpasar traditional market

\begin{tabular}{|c|c|c|c|c|}
\hline No & Market Name & Sample Code & Test Result & Information \\
\hline 1 & Yadnya Market & PT1 & $<3.6$ & MS \\
\hline 2 & Yadnya Market & PT2 & $<3.6$ & MS \\
\hline 3 & Yadnya Market & PT3 & $<3.6$ & MS \\
\hline 4 & Yadnya Market & PT4 & $<3.6$ & MS \\
\hline 5 & Gunung Sari Market & PT5 & $<3.6$ & MS \\
\hline 6 & Gunung Sari Market & PT6 & $<3.6$ & MS \\
\hline 7 & Gunung Sari Market & PT7 & $<3.6$ & MS \\
\hline 8 & Gunung Sari Market & PT8 & $<3.6$ & MS \\
\hline 9 & Gunung Sari Market & PT9 & $<3.6$ & MS \\
\hline 10 & Gunung Sari Market & PT10 & $<3.6$ & MS \\
\hline 11 & Gunung Sari Market & PT11 & $<3.6$ & MS \\
\hline 12 & Gunung Sari Market & PT12 & $<3.6$ & MS \\
\hline 13 & Gunung Sari Market & PT13 & $<3.6$ & MS \\
\hline 14 & Gunung Sari Market & PT14 & $<3.6$ & MS \\
\hline 15 & Tamba Market & PT15 & $<3.6$ & MS \\
\hline 16 & Tamba Market & PT16 & $<3.6$ & MS \\
\hline 17 & Tamba Market & PT17 & $<3.6$ & MS \\
\hline 18 & Tamba Market & PT18 & $<3.6$ & MS \\
\hline 19 & Tamba Market & PT19 & $<3.6$ & MS \\
\hline 20 & Tamba Market & PT20 & $<3.6$ & MS \\
\hline 21 & Tamba Market & PT21 & $<3.6$ & MS \\
\hline 22 & Tamba Market & PT22 & $<3.6$ & MS \\
\hline 23 & Tamba Market & PT23 & $<3.6$ & MS \\
\hline 24 & Waringin Market & PT24 & $<3.6$ & MS \\
\hline 25 & Waringin Market & PT25 & $<3.6$ & MS \\
\hline 26 & Waringin Market & PT26 & $<3.6$ & MS \\
\hline 27 & Waringin Market & PT27 & $<3.6$ & MS \\
\hline 28 & Waringin Market & PT28 & $<3.6$ & MS \\
\hline 29 & Waringin Market & PT29 & $<3.6$ & MS \\
\hline 30 & Waringin Market & PT30 & $<3.6$ & MS \\
\hline 31 & Waringin Market & PT31 & $<3.6$ & MS \\
\hline 32 & Waringin Market & PT32 & $<3.6$ & MS \\
\hline 33 & Waringin Market & PT33 & $<3.6$ & MS \\
\hline 34 & Waringin Market & PT34 & $<3.6$ & MS \\
\hline 35 & Waringin Market & PT35 & $<3.6$ & MS \\
\hline 36 & Penatih Market & PT36 & $<3.6$ & MS \\
\hline 37 & Penatih Market & РT37 & $<3.6$ & MS \\
\hline 38 & Penatih Market & PT38 & $<3.6$ & MS \\
\hline 39 & Penatih Market & PT39 & $<3.6$ & MS \\
\hline 40 & Penatih Market & PT40 & $<3.6$ & MS \\
\hline 41 & Tanjung Bungkak Market & PT41 & $<3.6$ & MS \\
\hline 42 & Tanjung Bungkak Market & PT42 & $<3.6$ & MS \\
\hline 43 & Tanjung Bungkak Market & PT43 & $<3.6$ & MS \\
\hline
\end{tabular}

\subsection{Water Content}

Based on the results of the research, the water content of the salted jengki fish samples circulating in traditional markets in East Denpasar meets SNI 8273-2016, namely a maximum of 40\%. From the test results, it was found that the sample moisture content was in the range $15.346 \%-23.044 \%$ in Table 4 and Figure 1. 


$$
\text { Table } 4
$$

Results of Testing the Water Content in Salted Anchovies Jengki Circulating in East Denpasar Traditional Market

\begin{tabular}{|c|c|c|c|c|}
\hline \multirow[t]{2}{*}{ No } & & \multirow[t]{2}{*}{ Market Name } & \multirow{2}{*}{$\begin{array}{l}\text { Sample Code } \\
\text { Test result }\end{array}$} & \multirow[t]{2}{*}{ Informatior } \\
\hline & & & & \\
\hline 1 & Yadnya Market & PT1 & 17.23 & MS \\
\hline 2 & Yadnya Market & PT2 & 17.30 & MS \\
\hline 3 & Yadnya Market & PT3 & 15.34 & MS \\
\hline \multirow[t]{2}{*}{4} & Yadnya Market & PT4 & 15.82 & \\
\hline & Gunung Sari Market & PT5 & 15.77 & MS \\
\hline 6 & Gunung Sari Market & PT6 & 16.90 & MS \\
\hline 7 & Gunung Sari Market & PT7 & 18.38 & MS \\
\hline 8 & Gunung Sari Market & PT8 & 16.24 & MS \\
\hline 9 & Gunung Sari Market & PT9 & 16.34 & MS \\
\hline 10 & Gunung Sari Market & PT10 & 16.72 & MS \\
\hline 11 & Gunung Sari Market & PT11 & 23.04 & MS \\
\hline 12 & Kertha Sari Village Market & PT12 & 17.24 & MS \\
\hline 13 & Kertha Sari Village Market & PT13 & 15.83 & MS \\
\hline 14 & Kertha Sari Village Market & PT14 & 16.47 & MS \\
\hline 15 & Tamba Market & PT15 & 17.52 & MS \\
\hline 16 & Tamba Market & PT16 & 15.53 & MS \\
\hline 17 & Tamba Market & PT17 & 18.00 & MS \\
\hline 18 & Tamba Market & PT18 & 17.59 & MS \\
\hline 19 & Tamba Market & PT19 & 19.92 & MS \\
\hline 20 & Tamba Market & PT20 & 18.01 & MS \\
\hline 21 & Tamba Market & PT21 & 17.29 & MS \\
\hline 22 & Tamba Market & PT22 & 16.17 & MS \\
\hline 23 & Tamba Market & PT23 & 16.60 & MS \\
\hline 24 & Kerta Waringin Market & PT24 & 17.24 & MS \\
\hline 25 & Kerta Waringin Market & PT25 & 16.85 & MS \\
\hline 26 & Kerta Waringin Market & PT26 & 18.98 & MS \\
\hline 27 & Kerta Waringin Market & PT27 & 17.03 & MS \\
\hline 28 & Kerta Waringin Market & PT28 & 17.11 & MS \\
\hline 29 & Kerta Waringin Market & Market & 17.63 & MS \\
\hline 30 & Kerta Waringin Market & РT30 & 15.83 & MS \\
\hline 31 & Kerta Waringin Market & PT31 & 16.33 & MS \\
\hline 32 & Kerta Waringin Market & PT32 & 15.43 & MS \\
\hline 33 & Kerta Waringin Market & PT33 & 17.12 & MS \\
\hline 34 & Kerta Waringin Market & PT34 & 17.14 & MS \\
\hline 35 & Kerta Waringin Market & PT35 & 17.71 & MS \\
\hline 36 & Penatih Market & PT36 & 17.46 & MS \\
\hline 37 & Penatih Market & PT37 & 16.93 & MS \\
\hline 38 & Penatih Market & PT38 & 15.99 & MS \\
\hline 39 & Penatih Market & PT39 & 16.30 & MS \\
\hline 40 & Penatih Market & PT40 & 19.25 & MS \\
\hline 41 & Tanjung Bungkak Market & PT41 & 15.84 & MS \\
\hline 42 & Tanjung Bungkak Market & PT42 & 15.87 & MS \\
\hline 43 & Tanjung Bungkak Market & PT43 & 18.09 & MS \\
\hline
\end{tabular}




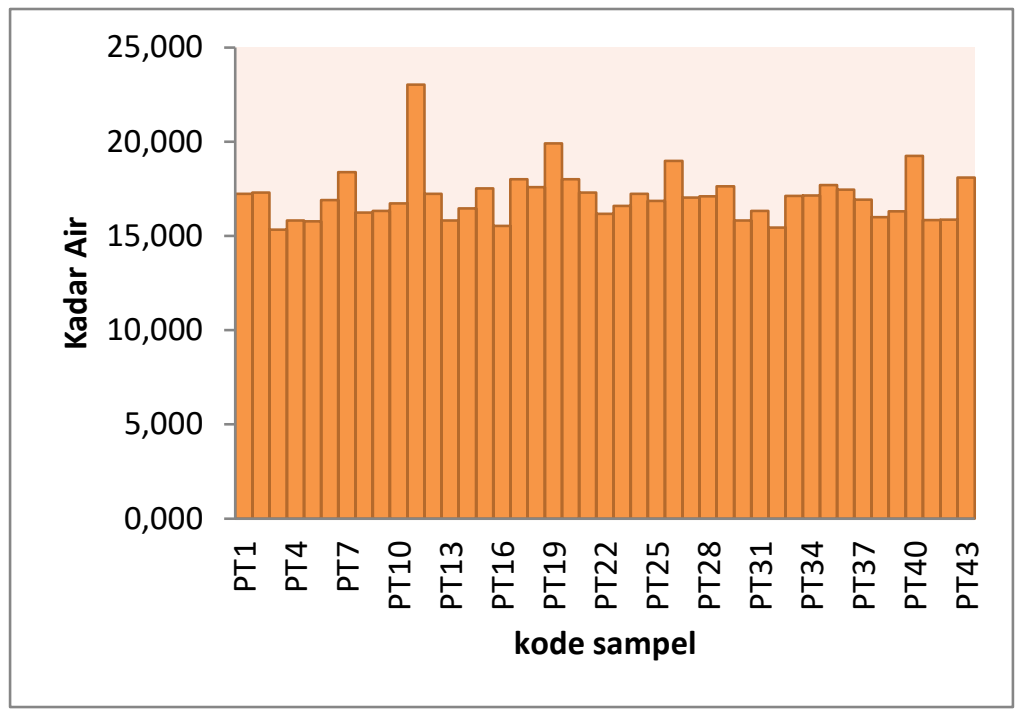

Figure 1

The water content of samples in salted anchovy jengki circulating in East Denpasar Traditional Market

The water content is influenced by the salt content during the processing of salted fish. The higher the salt content, the lower the water content in the material, this is because salt has hygroscopic properties so that it can absorb water contained in fish [5]. From the research results, the sample of salted anchovies has a water content that meets the predetermined standards. This shows that postprocessing such as marketing and storage is appropriate. During storage, the anchovies are not placed in open conditions because the salt contained in the anchovies can absorb air vapor in the surrounding environment and cause high water content in the product. High water content can affect the number of microorganisms in salted fish.

\subsection{Sensory Assessment}

The samples of salted anchovy anchovies circulating in traditional markets in East Denpasar were also subjected to organoleptic testing with variables of appearance, smell, taste, texture, and mushroom test results can be seen in Table 5 .

The organoleptic assessment aims to determine the panelist's assessment of the anchovies salted fish sample subjectively. Based on the assessment of appearance, the samples of salted anchovies received an assessment of their appearance from being dull to clean, bright, specific to species. The highest value with the sample code PT13 with a value of 8.33 is in the range 7-9. With clean specification criteria, bright to very bright, specific to type. The assessment of the dull anchovy salted fish was about $41.86 \%$ of the total sample. Anchovies salted fish that look dull is thought to be due to the unclean processing process and the presence of fungi that cause the fish to look unclean.

Based on the assessment of the smell of salted anchovies, it can be seen that the average results show a specific odor but less strong, the highest value is the sample code PT16 with a value of 8.60, which is in the range 7-9 With the criteria for the type specification is less strong to the specific type is strong. According to [6], the aroma of anchovies is the result of the activity of breaking down macromolecular compounds (proteins and fats) in fish into volatile compounds [7]. 


$$
\text { Table } 5
$$

Organoleptic Test Results (Appearance, Smell, Taste, Texture and Mushroom Presence) on Salted Jengki Anchovies Circulating in East Denpasar Traditional Market

\begin{tabular}{|c|c|c|c|c|c|c|c|c|c|c|}
\hline \multirow{2}{*}{$\begin{array}{c}\text { Sample Code } \\
\text { PT1 }\end{array}$} & \multicolumn{2}{|c|}{ Appearance } & \multicolumn{2}{|c|}{ Smell } & \multicolumn{2}{|c|}{ Taste } & \multicolumn{2}{|c|}{ Texture } & \multicolumn{2}{|c|}{ Mushrooms } \\
\hline & 5.67 & ijkl & 8.20 & $\mathrm{ab}$ & 8.33 & $a b$ & 8.60 & $\mathrm{a}$ & 9.00 & $\mathrm{a}$ \\
\hline PT2 & 7.00 & bcdef & 7.27 & cde & 7.27 & defg & 7.67 & bcd & 9.00 & $\mathrm{a}$ \\
\hline PT3 & 6.87 & cdefg & 7.27 & cde & 7.00 & fg & 7.13 & bcdef & 5.80 & $\mathrm{bc}$ \\
\hline PT4 & 7.80 & $\mathrm{Ab}$ & 7.00 & $\mathrm{e}$ & 7.53 & cdefg & 6.87 & def & 7.93 & $a b$ \\
\hline PT5 & 7.67 & $a b c$ & 7.00 & $\mathrm{e}$ & 7.13 & efg & 7.13 & bcdef & 5.80 & $\mathrm{bc}$ \\
\hline PT6 & 5.67 & ijkl & 7.80 & bcde & 7.13 & efg & 7.40 & bcde & 6.87 & $a b c$ \\
\hline PT7 & 7.80 & $\mathrm{ab}$ & 7.40 & cde & 7.40 & cdefg & 7.53 & bcd & 9.00 & $\mathrm{a}$ \\
\hline PT8 & 5.67 & ijkl & 7.13 & de & 7.27 & defg & 7.80 & $\mathrm{bc}$ & 6.87 & abc \\
\hline PT9 & 5.80 & hijkl & 7.40 & cde & 7.27 & $\operatorname{defg}$ & 7.00 & cdef & 9.00 & $\mathrm{a}$ \\
\hline PT10 & 6.47 & efghi & 8.20 & $\mathrm{ab}$ & 7.53 & cdefg & 7.00 & cdef & 8.47 & $\mathrm{a}$ \\
\hline PT11 & 7.00 & bcdef & 7.27 & cde & 7.13 & efg & 7.80 & $\mathrm{bc}$ & 6.87 & $a b c$ \\
\hline PT12 & 5.13 & 1 & 8.33 & $a b$ & 7.13 & efg & 7.13 & bcdef & 9.00 & $\mathrm{a}$ \\
\hline PT13 & 8.33 & $\mathrm{a}$ & 7.27 & cde & 7.27 & defg & 7.40 & bcde & 9.00 & $\mathrm{a}$ \\
\hline PT14 & 7.53 & bcd & 7.27 & cde & 7.67 & bcdef & 7.67 & bcd & 9.00 & $\mathrm{a}$ \\
\hline PT15 & 6.87 & cdefg & 7.13 & de & 7.53 & cdefg & 7.53 & bcd & 9.00 & $\mathrm{a}$ \\
\hline PT16 & 5.53 & $\mathrm{jkl}$ & 8.60 & $\mathrm{a}$ & 7.80 & abcde & 7.00 & cdef & 9.00 & $\mathrm{a}$ \\
\hline PT17 & 5.67 & ijkl & 7.93 & abcd & 7.93 & abcd & 7.00 & cdef & 9.00 & $\mathrm{a}$ \\
\hline PT18 & 6.60 & efgh & 7.67 & bcde & 7.00 & $\mathrm{fg}$ & 7.27 & bcdef & 9.00 & $\mathrm{a}$ \\
\hline PT19 & 5.27 & $\mathrm{kl}$ & 7.67 & bcde & 7.80 & abcde & 7.80 & bc & 9.00 & $\mathrm{a}$ \\
\hline РT20 & 5.27 & $\mathrm{kl}$ & 7.67 & bcde & 8.07 & $\mathrm{abc}$ & 7.00 & cdef & 7.40 & $\mathrm{ab}$ \\
\hline PT21 & 5.27 & $\mathrm{kl}$ & 7.93 & abcd & 7.80 & abcde & 7.00 & cdef & 9.00 & $\mathrm{a}$ \\
\hline PT22 & 6.87 & cdefg & 7.93 & abcd & 7.53 & cdefg & 7.00 & cdef & 9.00 & $\mathrm{a}$ \\
\hline PT23 & 6.07 & ghijk & 8.07 & $a b c$ & 7.53 & cdefg & 7.53 & bcd & 9.00 & $\mathrm{a}$ \\
\hline РT24 & 5.40 & $\mathrm{jkl}$ & 7.40 & cde & 8.33 & $\mathrm{ab}$ & 6.60 & ef & 6.87 & $a b c$ \\
\hline PT25 & 5.13 & 1 & 7.80 & bcde & 7.00 & $\mathrm{fg}$ & 6.47 & $\mathrm{f}$ & 6.87 & abc \\
\hline РT26 & 6.87 & cdefg & 7.27 & cde & 7.40 & cdefg & 7.67 & bcd & 9.00 & $\mathrm{a}$ \\
\hline PT27 & 7.27 & bcde & 7.80 & bcde & 7.80 & abcde & 7.13 & bcdef & 9.00 & $\mathrm{a}$ \\
\hline PT28 & 5.67 & ijkl & 8.20 & $\mathrm{ab}$ & 7.80 & abcde & 7.00 & cdef & 6.87 & $a b c$ \\
\hline РT29 & 7.00 & bcdef & 7.00 & $\mathrm{e}$ & 7.40 & cdefg & 7.93 & $\mathrm{ab}$ & 9.00 & $\mathrm{a}$ \\
\hline РT30 & 7.53 & bcd & 7.67 & bcde & 7.27 & defg & 7.27 & bcdef & 6.87 & $a b c$ \\
\hline РT31 & 6.60 & efgh & 7.27 & cde & 7.53 & cdefg & 7.13 & bcdef & 4.73 & $\mathrm{c}$ \\
\hline PT32 & 6.87 & cdefg & 7.80 & bcde & 7.40 & cdefg & 7.53 & bcd & 5.80 & $\mathrm{bc}$ \\
\hline PT33 & 6.60 & efgh & 7.27 & cde & 7.40 & cdefg & 6.87 & def & 9.00 & $\mathrm{a}$ \\
\hline PT34 & 5.67 & $\mathrm{ijkl}$ & 7.93 & abcd & 7.40 & cdefg & 6.87 & def & 9.00 & $\mathrm{a}$ \\
\hline PT35 & 5.40 & $\mathrm{jkl}$ & 8.47 & $\mathrm{ab}$ & 7.93 & abcd & 7.80 & $\mathrm{bc}$ & 6.87 & $a b c$ \\
\hline РT36 & 5.27 & $\mathrm{kl}$ & 7.80 & bcde & 8.47 & $\mathrm{a}$ & 7.40 & bcde & 6.87 & $a b c$ \\
\hline PT37 & 5.67 & $\mathrm{ijkl}$ & 8.20 & $\mathrm{ab}$ & 7.93 & abcd & 7.27 & bcdef & 9.00 & $\mathrm{a}$ \\
\hline PT38 & 6.73 & defg & 7.67 & bcde & 8.07 & $\mathrm{abc}$ & 7.13 & bcdef & 6.87 & $a b c$ \\
\hline PT39 & 6.20 & fghij & 7.67 & bcde & 7.40 & cdefg & 7.00 & cdef & 9.00 & $\mathrm{a}$ \\
\hline PT40 & 5.80 & hijkl & 8.33 & $\mathrm{ab}$ & 6.87 & $\mathrm{~g}$ & 7.53 & bcd & 9.00 & $\mathrm{a}$ \\
\hline PT41 & 6.73 & defg & 8.33 & $\mathrm{ab}$ & 7.40 & cdefg & 7.93 & $\mathrm{ab}$ & 9.00 & $\mathrm{a}$ \\
\hline PT42 & 6.87 & cdefg & 8.07 & $a b c$ & 8.07 & $\mathrm{abc}$ & 7.53 & bcd & 5.80 & $\mathrm{bc}$ \\
\hline PT43 & 6.20 & fghij & 8.20 & $\mathrm{ab}$ & 7.27 & defg & 7.13 & bcdef & 5.8 & $\mathrm{bc}$ \\
\hline
\end{tabular}

Note: The average value followed by the same letter in the same column is not significantly different at the Duncan test level of $5 \%$ 
The assessment of the texture of the anchovies was obtained from dry to less dry solids. The highest value with the sample code PT1 with a value of 8.60, which is in the range 7-9. With the criteria of being solid, less dry to dry. The texture of the anchovies is influenced by the water content in the fish. This is by the opinion of [5] which states that fish muscles and cells will be bound due to the release of water content in the fish body after drying and osmosis dehydration processes.

Based on the assessment by the panelists, from 43 samples of salted anchovies circulating in the East Denpasar Traditional Market, there are $55.81 \%$ of the samples that do not appear to be contaminated with mushrooms. For the assessment of mushrooms, namely values 1 and 9 with the criteria for number 1 there is no fungus and number 9 there is no fungus. According to [8], the greatest damage to salted anchovies is caused by insects, amounting to $66.67 \%$, while those caused by fungi are $26.98 \%$. The ease with which the salted anchovy fish is damaged by the fungus makes this product vulnerable to health hazards. if during storage it allows for mold growth, it will be damaged by these molds and will continue to increase with increasing storage time.

\section{Conclusion}

Research shows that 43 samples do not contain formalin. water content obtained by all samples met the requirements of SNI 8273: 2016. The results of the TPC test showed that 35 samples met the requirements and 8 samples exceeded the limits set by SNI 8273: 2016, namely the maximum limit of TPC contamination, namely $1.0 \times 105$ colonies/gram. E. coli testing from 43 samples fulfilled the SNI 8273: 2016 requirements, namely the maximum limit of E. coli contamination $<3.6 \mathrm{APM} /$ gram. From the results of the organoleptic test on appearance, smell, taste, texture, fungus, and overall acceptance, all assessments were significantly different, with the characteristics of a dull to bright clean appearance, specific to the type, specific odor but less strong, salty taste and a less specific type, dry solid texture too dense less dry.

\section{References}

[1] Habibah, T.P.Z., (2013). Identifikasi Penggunaan Formalin Pada Ikan Asin Teri Jengki dan Faktor Perilaku Penjual di Pasar Tradisional Kota Semarang, Unnes Journal of Public Health, (3) : 1-10

[2] Kementerian Kesehatan Republik Indonesia. (1988). Bahan Tambahan Makanan Nomor. 722/Menkes/Per/IX/88. Kemenkes RI. Jakarta.

[3] Estiasih, T. dan Ahmadi, K. (2009). Teknologi Pengolahan Pangan. PT. Bumi Aksara. Jakarta

[4] Mumpuni FS, Hasibuan S. (2018). Prevalensi mikroba pada produk pindang tongkol skala UKM di Pelabuhan Ratu, Sukabumi. Jurnal Pengolahan Hasil Perikanan Indonesia. 21(3): 480-485

[5] Rahman, T. (2014). Analisa Kadar Formalin Pada Ikan Asin Teri Jengki yang Dipasarkan di Kota Gorontalo [Tesis]. Gorontalo: Universitas Negeri Gorontalo.

[6] Winarno FG . (2004). Keamanan Pangan Jilid 1. Bogor: M-Brio Press.

[7] Daeng, R.A dan I.W. Laitupa. (2019). Karakteristik Kimia dan Evaluasi Sensori Produk Ikan Teri Kering Lokal di Desa Toniku. Jurnal Biosainstek. 2(1): 1-8.

[8] Lestari TB. (2000). Mempelajari Efektivitas khitosan dalam menghambat kerusakan ikan jambal roti yang diakibatkan oleh infestasi lalat dan pertumbuhan jamur. Skripsi. (Tidak dipublikasikan). Bogor: Fakultas Perikanan dan Ilmu Kelautan, Institut Pertanian Bogor. 